Oresta Karpenko, Doctor of Pedagogy, associate professor, Department of General Education and Early Childhood Education, Drohobych Ivan Franko State Pedagogical University, 24, Ivan Franko Str. Drohobych, Ukraine

\title{
ORGANIZATIONAL AND PEDAGOGICAL PRINCIPLES \\ OF CHILD CARE IN HALYCHYNA (1900-1939)
}

The article deals with the evolution of organizational forms of child care in Ukrainian Halychyna. Child care in Ukraine has always been one of the major social issues and found its expression in pedagogical theory and practice. Its theoretical principles were elaborated in Halychyna by I. Bartoshevskyi, M. Halushchynskyi, Yu. Dzerovych, I. Kalynovych, M. Konrad, A. Sheptytskyi, I. Yushchyshyn. The study aims to analyze theoretical principles of child care and their practical implementation in Halychyna in the first third of the 20th century. In the early 20th century orphan foundations were important means of supporting children and youth. Social assistance to orphans and socially unprotected children was associated with compassion and charity. The article provides an overview of activities of Orphan Council (a public parochial institution), "Shkilna Pomich" Association (1910) (School Aid), Ukrainian Regional Association for Children and Youth Protection (1917) whose task was to look after infants, preschool and school-age orphans, provide moral and religious education, satisfaction of vital needs, material support. The teachers demonstrated a high level of social responsibility, self-sacrifice and national consciousness. M. Halushchynskyi suggested dividing children under supervision into three age groups (4-7, 8-13 and 14-18 years old). The last two groups were further subdivided by gender (boys and girls). Playing was regarded as one of the specific forms of child-rearing capable of representing the community and national life in miniature. It is timely to retrieve Ukrainian traditions of child care in order to perfect current theories and practices.

Keywords: care, Orphan Council, "Shkilna Pomich", orphans, homeless children, Halychyna.

Подано до редакиії 08.02.2017

Рецензент: д. пед. н., проф. М. М. Чепіль

УДК: 372.881 .116 .12

DOI: https://doi.org/10.24195/2414-4665-2017-2-8

Ольга Михайлівна Хома, кандидат педагогічних наук, дочент кафедри теорії та методики початкової освіти, Мукачівський державний університет, вул. Ужгородська, 26, Мукачево, Україна

\section{РОЗВИТОК ЛЕКСИЧНОЇ КОМПЕТЕНЦЇ̈ МОЛОДШИХ ШКОЛЯРІВ НА УРОКАХ УКРАЇНСЬКОЇ МОВИ}

У статті розкривається проблема розвитку лексичної компетенції на уроках української мови, щуо є складовою мовної. Зосереджено увагу на нових вимогах до навчання рідної мови в сучасних умовах реформування освіти. 3'ясовано зміст вивчення лексичних понять, указано програмові вимоги до них. Сформульовано напрями, етапи, систему їх вивчення на уроках. Розвиток лексичної компетенції визначено як поетапне засвоєння лексичних понять у мовній системі, сформованість мовленнєвих лексичних умінь $і$ навичок, здатність застосувати їх у процесі спілкування. Виокремлено найбільш ефективні методи і прийоми засвоєння основ лексикології.

Ключові слова: мовна компетенція, лексична компетенція, словниковий склад мови, методи навчання основ лексикології, вправи.

Постановка проблеми. Початкова освіта в Україні стала на шлях реформування. Основне завдання, яке стоїть перед школою, полягає у переході від знаннєвої парадигми до компетентнісної. Реалізація компетентнісного підходу передбачає спрямованість навчання на розвиток $\mathrm{i}$ формування ключових компетенцій. У цьому процесі важливе місце посідає вивчення української мови. Це не тільки предмет у системі початкової освіти, а засіб соціалізації особистості, опанування знаннями з інших наук.

Важливо зазначити, що мова $\epsilon$ носієм національної культури, духовності, засобом національно-патріотичного виховання, і роль учителя в становленні мовленнєвої особистості є провідною. 
«Школа стає справжнім осередком культури лише тоді, коли в ній панують чотири культи: культ Батьківщини, культ людини, культ книжки і культ рідного слова» [6, с. 201]. Збагачення, активізація, уточнення словника молодших школярів, засвоєння основ лексикології сьогодні є вкрай важливими завданнями. «Робота над вивченням лексичного матеріалу в початкових класах має велике загальноосвітне і практичне значення. Вивчення його розширює знання учнів про мову, ознайомлює з одиницею мови - словом, є головним джерелом збагачення словника учнів» [2, с. 135].

Виходячи 3 цього, оновлена програма 3 української мови (2016-2017 року) націлює вчителя на формування ключової комунікативної компетентності молодшого школяра, яка виявляється у здатності успішно користуватися мовою (всіма видами мовленнєвої діяльності) в процесі спілкування, пізнання навколишнього світу, вирішення життєво важливих завдань. Слово $є$ базовою одиницею у побудові діалогічного і монологічного мовлення.

Аналіз останніх досліджень і публікацій. Концепція навчання і виховання засобом рідного слова сформульована у працях В. Сухомлинського. «Чим глибше людина пізнає тонкощі рідної мови, тим тонша іiі сприйнятливість до гри відтінків рідного слова, тим більше підготовлений іï розум до оволодіння мовами інших народів, тим активніше сприймає серце красу слова» [6, с. 202]. У сучасних умовах функціонування національної системи освіти й виховання в Україні творча спадщина В. Сухомлинського набуває нового змісту.

Сьогодні дослідженням означеної проблеми за різними напрямами займається низка науковців (А. Богуш, М. Вашуленко, О. Вашуленко, О. Соловйова, Л. Паламар, О. Хорошковська, Н. Чепелюк та інші). Відтак, М. Вашуленко розкриває методику вивчення елементів лексикології [2], О. Хорошковська аналізує способи семантизації слова [7], Н. Чепелюк в дисертаційному дослідженні пропонує систему вправ, спрямованих на збагачення словникового запасу учнів початкових класів дієслівними формами [9]. Н. Сіранчук розкриває шляхи формування лексичної компетентності молодших школярів засобами лексичних вправ [5].

Мета статті - 3'ясувати систему та методи розвитку лексичної компетенції на уроках української мови в початковій школі. Завдання - розкрити сучасні підходи до засвоєння основ лексикології в 2-4 класах.

Методи наукового дослідження проблеми розвитку лексичної компетенції: теоретичний аналіз, спостереження за уроками української мови в початковій школі, бесіда з учителями та учнями.

Виклад основного матеріалу дослідження. На початковому етапі дослідження нами проводився аналіз мовлення молодших школярів. 3'ясовано, що їхня лексика насичена діалектними словами (властиво для Закарпаття), здебільшого словами в прямому значенні, відсутні фразеологічні одиниці. У процесі складання зв'язних висловлювань спостерігаються зайві слова, тавтологія. Тому нами закцентовано увагу на методиці розвитку лексичної компетенції на уроках української мови, на теоретичних і практичних іiі засадах.

У Великому тлумачному словнику сучасної української мови подається визначення поняття «компетентний», компетенція. «Компетентний: 1) який має достатні знання в якій-небудь галузі; який 3 чим-небудь добре обізнаний, тямущий // який грунтується на знанні; кваліфікований». «Компетенція - 1) добра обізнаність із чим-небудь; 2) коло повноважень якої-небудь організації, установи, особи» [3, с. 443]. Поняття «компетентність» i «компетенція» $\epsilon$ різними, проте взаємопов'язаними. Лексична компетенція - складова мовної, разом 3 фонологічною, морфологічною, синтаксичною стають підгрунтям для формування комунікативної компетентності. Тому результатом оволодіння лексичною компетенцією є набуття молодшими школярами лексичної компетентності. За словами М. Вашуленка, «зробити мовну і мовленнєву теорію функціональною, домогтися усвідомленого застосування учнями мовних і мовленнєвих понять, правил, приписів у навчальних i пізнавальних життєвих ситуаціях спілкування - одне 3 найважливіших завдань учителя початкових класів у здійсненні ним мовної освіти молодших школярів» $[1$, с. 16]. Виходячи 3 цього, ми розглядаємо розвиток лексичної компетенції як поетапне засвоєння лексичних понять у мовній системі, сформованість мовленнєвих лексичних умінь i навичок, здатність застосувати їх у процесі спілкування. Ми розглядаємо лексичну компетенцію не тільки як суму знань, а як таку, що базується на знаннях, цінностях, здібностях, одержаних у процесі засвоєння основ лексикології.

Найбільш доцільним вважаємо виділення чотирьох напрямів засвоєння лексичних понять (за М. Вашуленко):

1. Лексичний аналіз мови художніх текстів: виявлення незнайомих слів і висловів, уточнення відтінків значень окремих слів і висловів; виявлення слів, ужитих у переносному значенні; з'ясування смислових відтінків ужитих у тексті синонімів, антонімів; аналіз інших зображувальних засобів, зокрема порівнянь.

2. Пояснення значення слів шляхом використання різних способів: показ предметів чи дій, демонстрація малюнків, слайдів із зображенням предметів, назви яких $є$ новими для дитини, добір синонімів, антонімів, уведення нового слова до контексту тощо.

3. Виконання завдань на добір слів із певним значенням: дібрати 3 поданого синонімічного ряду потрібні за смислом речення іменники; дібрати прикметники 3 переносним значенням для опису предметів, характеристики людини, опису ii зовнішності, настрою, свого ставлення до події, до товариша тощо. 
4. Уведення поданих або самостійно дібраних лексем у власне мовлення школярів: складання речень і текстів за опорними словами, заміна слів у реченнях відповідними синонімами чи антонімами, редагування поданих текстів тощо [2, с. 136-137].

У практиці роботи початкової школи склалася така поетапність процесу вивчення лексики: пропедевтичний (підготовчий) етап (1, 2 класи), спеціальний (3 клас) і аспектний, або етап удосконалення лексикологічних умінь (4 клас).

Ураховуючи це, нами визначено систему ознайомлення учнів 3 лексичними поняттями в 1-4 класах:

- ознайомлення учнів 3 лексичними явищами в процесі навчання грамоти (тлумачення лексичного значення слів);

- оволодіння теоретично-практичними відомостями з теми у розділі «Слово» та у процесі вивчення граматичних понять;

- автоматизація дій учнів $з$ новими лексичними поняттями (на основі мовних, мовленнєвих вправ);

- формування комунікативних умінь (уміння застосовувати лексичні одиниці в процесі спілкування, у побудові діалогів, монологів).

Лексикологія вивчає словниковий склад мови у різних аспектах: групування слів за значенням (однозначність і багатозначність, пряме і переносне, конкретне і абстрактне, омоніми, синоніми, антоніми), стилістична диференціація лексики сучасної української літературної мови (загальновживана, специфічно побутова, офіційно-ділова, виробничо-професійна, емоційна тощо), склад лексики 3 погляду походження (запозичена і власне українська), за часом утворення (застарілі слова і нові). У початковій школі вивчається тільки перша група слів за значенням; 3 погляду походження, вживання та часом утворення ознайомлення відбувається практично на основі взірця, вправ із підручників з української мови.

У Державному стандарті початкової загальної освіти галузі «Мови і літератури» [4] й оновленій навчальній програмі 3 української мови подається зміст вивчення основ лексикології в початковій школі. Учні повинні вміти пояснювати пряме і переносне значення слів, розпізнавати в текстах і пояснювати синоніми, антоніми, омоніми, найуживаніші фразеологізми; використовувати здобуті знання з лексики у власному мовленні; уміти користуватися навчальними словниками різних типів.

Методи навчання можуть бути різними: пояснення, евристична бесіда, спостереження над мовою, робота 3 підручником, пояснювально-ілюстративні, інтерактивні, проблемно-пошукові, ігрові, практичні вправи. Пропонуємо фрагмент уроку.

Тема: «Слова, що звучать однаково, але мають різне значення».

Етап уроку: пояснення нового матеріалу. Метод евристичної бесіди.

Учитель пропонує предметні малюнки, на якому зображені коса дівчини і коса - знаряддя праці.
- Що ви бачите на першому малюнку?

- Це коса дівчини.

- Що ви бачите на другому малюнку?

- Це знаряддя праці.

- Як звучать ці слова?

- Ці слова звучать однаково.

- Чи однакове мають значення?

- Hi.

- Складіть речення з цими словами.

- Отже, учні, в українській мові $є$ слова, які однаково звучать, але мають різне значення (омоніми).

Алгоритм пояснення означеної теми такий: а) бесіда за предметними малюнками; б) спостереження за вживанням слів; в) уведення слова в контекст; г) ознайомлення 3 новим лексичним поняттям; д) робота 3 підручником.

Цю ж тему можна пояснити проблемнопошуковим методом на основі тексту. Учням пропонується текст i за допомогою шкільного тлумачного словника 3'ясовується лексичне значення виділених слів, надалі формулюються висновки. Орієнтовний текст:

«Закарпаття розташоване на заході нашої України. Воно славиться багатими лісами, мінеральними водами, працьовитими й щирими людьми. Туристів приваблює замок Паланок. У лісах можна назбирати білих грибів, лисичок».

Основним підходом до вивчення будь-якої теми 3 основ лексикології $є$ збагачення словникового запасу рідної мови 3 погляду стилістичного вживання та призначення слів у мовленні. Таке вивчення лексичних понять має виразно практичне спрямування й допомагає учням оволодіти багатством рідної мови, відповідально ставитися до вибору слів у процесі спілкування.

Ознайомлення учнів із синонімічним багатством мови, формування навичок добирати синоніми залежно від мовленнєвої ситуації - один з ефективних засобів збагачення словникового запасу i основа формування їхніх мовленнєвих навичок.

У процесі опрацювання синонімів учителю необхідно враховувати два аспекти: момент тотожності або близькості значення і момент різниці - смислові відтінки, різне емоційне й стилістичне забарвлення. Пропонуємо це лексичне поняття розглядати за допомогою пояснювально-ілюстративних, інтерактивних методів навчання на основі аналізу тексту. Слід зауважити, що в учнів формуються уміння під керівництвом учителя добирати синоніми до стійких словосполучень (фразеологізмів).

Як показує наше спостереження за уроками української мови в початковій школі, молодші школярі краще сприймають і усвідомлюють значення антонімів, ніж синонімів. Опрацювання антонімів має передусім практично-мовленнєве значення. Завдання його - показати, що використання антонімів у мовленні робить його змістовним, допомагає змальовувати протилежні за значенням предмети. 
Аналіз предметних малюнків дасть можливість зрозуміти учням природу цього лексичного поняття.

Вважаємо, що в основі ознайомлення з лексичними поняттями має бути семантика слова в єдності з його звуковою і графічною формами. У методиці існують різні прийоми семантизації, тобто тлумачення значень слів: добір синонімів, антонімів, пояснення будови слова, робота зі шкільними тлумачними словниками, контекст та інші. Всі зазначені засоби семантизації можуть супроводжуватися використанням наочності (комп’ютерних технологій), що впливає на сприймання образу слова разом з його предметним значенням.

Проведена нами бесіда 3 учнями 2 класу (які у тебе відчуття від слів «сонечко», «мама») показало, що майже у 90 відсотків 3 них у процесі складання висловлювань з'явилися позитивні емоції. Ми говоримо про властивість слова впливати на почуття, а через них - на розум і характер особистості. Тому вважаємо, що застосування прийому сугестії $\epsilon$ доцільним, оскільки грунтується на властивості слова відображати оточуючий світ різними барвами. Завдання вчителя - розвивати в молодших школярів позитивні емоції, віру в себе, виховувати громадянський образ поведінки.

3 метою формування в учнів критичного мислення рекомендуємо застосовувати прийоми: круги Ейлера, що дасть можливість їм порівнювати, узагальнювати слова, встановлювати нові асоціації, сенкану, складання кластерів тощо. Виходячи із сучасних вимог до уроків української мови в початковій школі, застосування дидактичних ігор для активізації словника $€$ необхідною умовою. Нами запропоновано окремі ігри, що збагачують активний словник учнів, формують культуру усного українського мовлення, виховують любов до рідного слова. [8]. До прикладу:

Гра «Український віночок».

Обладнання: різнокольорові пелюстки із паперу, український вінок.

Хід гри. Учитель роздає учням різнокольорові пелюстки зі словами -іменниками, що належать до чоловічого, жіночого, середнього родів. Школярі за завданням учителя, працюючи в групах, умовно сплітають «іменниковий віночок». Перемагає та група, яка швидше сплете віночок.

Для «віночка» вчитель може запропонувати слова, що тематично об'єднані (наприклад, герб, прапор, тризуб, калина, мова, держава та інші).

Учні виконують і додаткові завдання: пояснити лексичне значення окремих слів, стійких словосполучень, дібрати синоніми, антоніми, скласти речення, побудувати діалог на визначену тему, скласти зв'язне висловлювання.

Зв'язок лексики із граматикою дозволяє розглядати слово в єдності змісту і форми, тобто семантики і граматичних ознак, що в свою чергу дає можливість учням під час вивчення частин мови і основ синтаксису чітко розмежовувати лексико-граматичні і лексичне значення кожного слова в межах однієї частини мови чи речення. Ми акцентуємо увагу на комплексному підході у вивченні основ лексикології.

Попередити лексичні помилки в усному і писемному мовленні молодших школярів за допомогою вправ - одне із основних завдань учителя.

Добір лексичних вправ залежить від змісту і специфіки виучуваних лексичних понять. Серед них такі: 1) тлумачення лексичного значення слова за допомогою словника; 2) визначення лексичного і граматичного значень слова; 3) складання речень за опорними словами, сюжетним малюнком; 4) добір синонімів, антонімів 5) складання речень із багатозначними словами, прямим і переносним значеннями; 6) побудова зв'язних висловлювань; 7) редагування тексту.

Практика роботи в початковій школі дала можливість виокремити лексико-семантичні вправи, що сприяють формуванню національної свідомості у молодших школярів засобом слова. Серед них: аудіювання тексту про історію нашої країни, яскравих особистостей, вправа «Поповнюю свій словник» (активізація і збагачення словника молодшого школяра), мовні хвилинки - орфоепічні, орфографічні, каліграфічні, вправи «Говори красно», вправи із застосуванням тексту, комунікативні завдання.

Одна із запропонованих нами вправ: «Поповнюю свій словник». Рекомендуємо вчителю розпочинати урок рідної мови із лексико-етимологічної хвилинки «У світі слів моєї країни». Учні записують слова (наприклад, народ, прапор, гімн України, Батьківщина та інші), за допомогою тлумачного шкільного словника пояснюють лексичне значення, вчитель доповнює розповіддю про їхню етимологію.

3 метою формування комунікативного мовлення пропонуємо такі орієнтовні завдання:

а) уявіть собі ситуацію: до Вас приїхали друзі 3 Угорщини. Що розкажете їм про звичаї українського народу?;

б) складіть діалог розмови 3 письменником, художній текст якого прочитали на уроці літературного читання;

г) доберіть прислів'я і приказки про працьовитість нашого народу;

в) складіть твір-есе «Чому треба знати про синоніми».

Вправи такого типу сформують в учнів комунікативні уміння, сприятимуть розвиткові усного мовлення, виховуватимуть гордість за рідну мову, рідну культуру.

Висновки і перспективи подалыших досліджень. Таким чином, досліджено напрями, методи розвитку лексичної компетенції на уроках української мови в початковій школі. Серед методів такі: пояснення, евристична бесіда, спостереження над мовою, робота 3 підручником, пояснювально-ілюстративні, інтерактивні, проблемнопошукові, ігрові, практичні вправи. Запропоновано прийоми засвоєння основ лексикологіі. Перспективу подальшого дослідження вбачаємо у визначенні інноваційних методів навчання лексичних понять. 


\section{ЛІТЕРАТУРА}

1. Вашуленко М. С. Компетентнісний підхід до перевірки мовних і мовленнєвих знань молодших школярів / М. С. Вашуленко // Початкова школа. №1. - 2009. - С.16-17.

2. Вашуленко М. С. Методика навчання української мови в початковій школі: навчальнометодичний посібник для студентів вищих навчальних закладів / За наук. ред. М. С. Вашуленка - К.: Літера ЛТД, 2010. - 364 с.

3. Великий тлумачний словник сучасної української мови / Уклад. і головн. ред. В. Т. Бусел. К.: Ірпінь: ВТФ «Перун», 2001. - 1440 с.

4. Державний стандарт початкової загальної освіти // Початкова освіта. - №18, травень, 2011. C.8-30.

5. Сіранчук Н. Формування лексичної компетентності молодшого школяра засобом словотворчих вправ / Н. Сіранчук // Початкова школа -№2. -2016 . - C. $4-8$.

\section{REFERENCES}

1. Vashulenko, M. S. (2009). Kompetentnisnyi pidkhid do perevirky movnykh i movlennievykh znan molodshykh shkoliariv [Competence approach to assessing language and speech skills in primary school students]. Pochatkova shkola - Primary school, 1, 16-17 [in Ukrainian].

2. Vashulenko, M. S. (2010). Metodyka navchannia ukrainskoi movy $v$ pochatkovii shkoli: navchalnometodychnyi posibnyk dlia studentiv vyshchykh navchalnykh zakladiv [Methods of teaching Ukrainian in primary school: textbook for university students]. Kyiv: Litera LTD [in Ukrainian].

3. Busel, V. T. (2001). Velykyi tlumachnyi slovnyk suchasnoi ukrainskoi movy [Great dictionary of modern Ukrainian language]. Kyiv: Irpin: VTF «Perun» [in Ukrainian].

4. Derzhavnyi standart pochatkovoi zahalnoi osvity [State standard of primary education]. (2011). Pochatkova osvita - Primary education, 18, 8-30 [in Ukrainian].

5. Siranchuk, N. (2016). Formuvannia leksychnoi kompetentnosti molodshoho shkoliara zasobom slovotvorchykh vprav [Forming lexical competency of primary school students by means of word-forming exercises]. Pochatkova shkola Primary school, 2, 4-8 [in Ukrainian].
6.Сухомлинський В. О. Серце віддаю дітям / В. О. Сухомлинський: Вибрані твори в 5-ти томах. Т. 3. - К.: «Радянська школа», 1977. - 670 с.

7. Хорошковська О. Н. Методика навчання української мови у початкових класах шкіл 3 російською мовою викладання / О. Н. Хорошковська. - К.: Промінь, 2006. - 256 с.

8. Хома О. М. Дидактична гра як один із засобів пізнавальної діяльності учнів на уроках української мови в початковій школі / О. М. Хома. // Педагогічні науки: теорія, історія, інноваційні технології. - Суми, Сум ДПУ імені А. С. Макаренка, 2016. - С.111-121.

9. Чепелюк Н. І. Збагачення словникового запасу учнів початкових класів дієслівними формами: автореф. дис. на здобуття наук, ступеня канд. пед. наук: 13.00.02 теорія і методика (укр.мова) / Н. I Чепелюк. Одеса: Південноукр. держ. пед. ун-т ім. К. Д. Ушинського, 2001. - 21c.

6. Cukhomlynskyi, V. O. (1977). Sertse viddaiu ditiam [I give my heart to children]. Vybrani tvory $v$ 5-ty tomakh - Selected works in 5 volumes. (Vol. 3). Kyiv: Radianska shkola [in Ukrainian].

7. Khoroshkovska, O. N. (2006). Metodyka navchannia ukrainskoi movy u pochatkovykh klasakh shkil z rosiiskoiu movoiu vykladannia [Methods of teaching Ukrainian in primary school with the Russian language of teaching]. Kyiv: Promin [in Ukrainian].

8. Khoma, O. M. (2016). Dydaktychna hra yak odyn iz zasobiv piznavalnoi diialnosti uchniv na urokakh ukrainskoi movy v pochatkovii shkoli [Didactic game as one of means of students' cognitive activity at Ukrainian language lessons in primary school]. Pedahohichni nauky: teoriia, istoriia, innovatsiini tekhnolohii - Pedagogical sciences: theory, history and innovation technologies (pp. 111-121). Sumy [in Ukrainian].

9. Chepeliuk, N. I. (2001). Zbahachennia slovnykovoho zapasu uchniv pochatkovykh klasiv diieslivnymy formamy [Enriching primary school students' vocabulary with verbs]. Extended abstract of candidate's thesis. Odesa: Pivdennoukr. derzh. ped. un-t im. K. D. Ushynskoho [in Ukrainian].

\section{PhD (Candidate of Pedagogical Sciences), associate professor, Department of Theory and Methods of Primary Education, Mukachevo State University, 26,Uzhhorodska Str., Mukachevo, Ukraine}

\section{DEVELOPMENT OF PRIMARY SCHOOL STUDENTS' LEXICAL COMPETENCE AT UKRAINIAN LANGUAGE LESSONS}

The article deals with the issue of primary school students' lexical competence as a component of more general language competence. It aims to reveal different approaches to mastering the bases of lexicology in the $2^{\text {nd }}-4^{\text {th }}$ grades. On the basis of observation and talking to primary school students it has been revealed that their vocabulary is rich with dialect words used in direct meaning; they almost never use phraseological units. When making sentences and stories, 
they use a lot of improper words, tautology. The development of lexical competence is considered as a step-by-step mastering of lexical concepts in the language system, maturity of lexical skills, ability to use them when speaking. The following methods of teaching lexical units are suggested: explanation, heuristic conversation, language observation, work with a textbook; as well as interactive, gaming and practical tasks. A fragment of a lesson has been suggested in the paper using didactic games, for example, "Ukrainian Chaplet". The experience of working at primary school has made it possible to emphasize the following lexical and semantic exercises contributing to the formation of children's national consciousness: listening comprehension of texts about Ukraine, exercise "Enriching one's vocabulary", "Speak oratorically", working with texts, interactive communicative exercises, etc. A teacher can also use such methods of enriching children's vocabulary: interpretation of a lexical meaning of a word by means of a dictionary; finding lexical and grammatical meaning of a word; making sentences using key words, finding synonyms, antonyms, text revision. One of the main tasks of a teacher is to prevent lexical mistakes in written and oral language of primary school students. The teaching methods and exercises will help to form primary school students' communication skills and contribute to the development of their speaking.

Keywords: language competence, lexical competence, vocabulary, teaching methods, exercises.

Подано до редакиії 09.02.2017

Рецензент: д. пед. н., проф. Г. В. Товканеичь

UDC: $376.1: 316.472 .3$

DOI: https://doi.org/10.24195/2414-4665-2017-2-9

Tamila Kolomoiets, PhD (Candidate of Sociological Sciences), senior lecturer, Kryvyi Rih State Pedagogical University, 54, Haharina avenue, Kryvyi Rih, Ukraine

\section{SOCIALIZATION MODEL OF PRESCHOOLERS WITH SPECIAL NEEDS IN THE SYSTEM OF SPECIAL EDUCATION}

Modern social relations in our country are far from being harmonious. As to educational system, such disharmony is even stronger because it is expressed in separating of mass and correctional education. Attempts to form inclusive education have not come to any considerable results, which appears in constant division of children into "normal majority" and "abnormal minority". That is why the issue of socialization of preschool children with special needs becomes more and more important. The review of some scientific works has shown that the issue of forming mechanisms of interaction between the teachers of special educational institutions and their students towards improving the efficiency of their socialization is still understudied. The paper is aimed at the formation of interaction model between special educational institutions teachers and their students towards increasing the efficiency of their socialization. The further education of children with special needs will be easier if their socialization and social adaptation in the social environment begin in the preschool age. Under these conditions their future life and professional activities will be more socially adapted. The developed model makes it possible to perform such tasks of socialization of children with special needs: acquisition of abilities and skills needed for normal functioning of these children in the society; forming adequate social behavior, social "self"; mastering the norms of culture, etc.

Keywords: special education, inclusive education, socialization, children with special needs, psychophysical disturbances, social adaptation, preschool education.

\section{Introduction}

Modern social relations in our country are far from being harmonious. As to educational system, such disharmony is even stronger, because it is expressed in separating of mass and correctional education. Attempts to form inclusive education have not come to any considerable results, which appears in constant division of children into "normal majority" and "abnormal minority". That is why the issue of socialization of preschool children with special needs is of specific importance.
In the process of literature review, three groups of scientists, whose works were of interest in the context of this study, were distinguished. Firstly, works that concern socialization as a phenomenon and a process were studied. In this regard, thoughts of G. Andreeva, E. Andrienko, S. Litvinenko, B. Lomov, M. Lukashevych, V. Moskalenko, S. Savchenko, T. Semygina appeared to be interesting. Secondly, views of scholars on the peculiarities of socialization of children of preschool age were considered (A. Mudryk, V. Mukhina, A. Kapska, T. Kravchenko, I. Rogalska). Thirdly, scholars V. Arbe- 